\title{
Characterization of acetic acid fermentation of detoxified Rhus verniciflua vinegar produced by various yeast strains
}

\author{
Ji-Seon Kim, Soo-Hwan Yeo, Ji-Young Mun, Seong Yeol Baek* \\ Department of Agro-food Resource, National Institute of Agricultural Science, RDA, Wanju 55365, Korea
}

\section{효모 종류에 따른 무독화 옻식초의 초산발효 특성}

\author{
김지선 · 여수환 · 문지영 · 백성열* \\ 국립농업과학원 농식품자원부
}

\begin{abstract}
This study was conducted to investigate and compare the characteristics of acetic acid fermentation in detoxified Rhus verniciflua vinegar (DRV) produced by different yeast strains. The DRVs were prepared by static acetic acid fermentation using six different yeast strains (Saccharomyces cerevisiae Fermivin, Pichia kudriavzerii N77-4, Hanseniaspora pountiae HP1-2, Candida tropicalis Y447, Wickerhamomyces anomalus N43-8, and Pichia kluyveri Frootzen). Alcohol content of the $S$. cerevisiae Fermivin fermented DRV was highest $16.07 \%$. Among the yeast strain DRVs, there were significant differences in alcohol content, but all alcohol levels were $11 \%$. Moreover, there were differences in $\mathrm{pH}$ and titratable acidity of the DRVs. The organic acid content of the DRVs ranged from 35.88 to $55.49 \mathrm{mg} / \mathrm{mL}$ and there were significant differences among the yeast strain DRVs. Essential free amino acids, particularly glutamic acid, alanine, leucine and valine, were detected in each of the 6 DRVs. Electronic nose analysis revealed that three different volatile chemical pattems were present in the 6 DRVs. The results indicate that yeast strains with different characteristics can produce vinegars with different characteristics.
\end{abstract}

Key words : vinegar, yeast, fermentation, Rhus verniciflua, acetic acid

\section{서 론}

식초는 음식의 맛을 돋워주는 산미료이며 발효과정에서 생성된 독특한 향과 신맛을 갖는 대표적인 발효식품이다 (1). 이러한 식초는 과일, 곡류 등 당이나 전분질을 함유한 원료로 하여 효모에 의해 당이 알코올이 되고, 초산균에 의해 알코올이 초산으로 산화되는 2 단계 발효 과정으로 만들어진다(2). 초산발효과정에서 효모와 초산균은 휘발성 및 비휘발성 물질인 당, 유기산, 아미노산, 고급 알코올, 에스테르 등을 생산하여 식초 특유의 풍미와 감미를 나타낸 다(3). 식초에는 다양한 원료가 사용되어 원료로부터 유래

*Corresponding author. E-mail : dunkbis@korean.kr Phone : 82-63-238-3609, Fax : 82-63-238-3843

Received 10 October 2016; Revised 27 October 2016; Accepted 27 October 2016.

Copyright (c) The Korean Society of Food Preservation. All rights reserved.
된 기능성 성분이 함유된 식초 개발과 관련한 연구들이 다수 진행되었다. Ann 등(4)은 홍삼식초 섭취 시 체중을 감소시켜 비만 억제 효과가 있다고 하였다. 감식초는 혈중 low-density lipoprotein(LDL) 콜레스테롤을 낮추고, high-density lipoprotein(HDL) 콜레스테롤은 상승시키고 간과 근육에 함유되어 있는 glycogen을 증가시켜 신체 활동 증대에 효과가 있음을 보고하였다(5). 미나리 식초의 acetic acid는 TCA 회로의 활성화를 도와 젖산분해를 촉진하고 aspartic acid는 피로 회복 효과를 갖는다고 보고하였다(6). 무화과 식초는 $\gamma$-amino butyric $\operatorname{acid(GABA)}$ 함량이 높아 성인병 예방과 청소년기의 학습능력 증진 효과가 있으며, 오이식초는 혈장 acetaldehyde 농도를 낮추어 숙취 해소 효과가 있는 것으로 보고되었다 $(7,8)$. 옻식초에 사용된 옻 은 수포, 가려움, 발진 등의 접촉성 피부염을 유발하는 우루 시올(urushiol) 성분을 가지고 있으나 당뇨병과 위장병 치료 를 위해 전통적으로 닭과 오리 등을 조리할 때 첨가하여 먹어왔다(9). 옻에 함유된 폴리페놀 및 플라보노이드 성분 
은 항산화, a-glucosidase 억제 효과 등이 있는 것으로 알려 져 있다(10-12). 최근 식초 시장은 단순 조미식품에서 기능 성 음료 및 조미 식초로 소비패턴이 변화하여 기호성이 향상된 고품질 발효식초가 등장하고 있다(13). 그러나 전통 방식인 병행복발효 식초는 발효과정에서 생성되는 풍부한 향미가 있는 반면에 이미나 이취의 발생과 수율이 낮아 대량 생산 시 문제점이 있어 이에 대한 연구가 필요한 시점 이다(14). 국내 곡물식초는 발효방법, 미생물의 종류, 발효 조건 및 숙성기간, 원료의 상태 등 여러 요인에 의해 다양한 향기성분들이 생성되어 복합적인 향미를 갖는 것으로 보고 되었다(15). 유럽에서는 Saccharomyces 속 효모가 아닌 야 생 효모에 대한 관심과 연구가 증가되고 있는데, 특히 non-Saccharomyces 속 야생효모는 다양한 효소를 생산하여 주류의 향미 형성에 중요한 역할을 한다고 보고되었다(3). 식초의 기질이 되는 술의 원료, 발효 방법 특히 효모 등에 의한 식초의 유기산 및 휘발성 성분에도 차이가 있을 것으 로 생각된다(16).

\section{재료 및 방법}

\section{실험재료}

본 연구에 사용된 옻(Rhus verniciflua)은 2012년 4월 충북 옥천산 옻나무 껍질을 구입하여 사용하였으며, Choi 등(17) 의 방법에 따라 옻나무 껍질을 $2 \times 2 \mathrm{~cm}$ 크기로 자른 후 수분이 통할 수 있는 자루에 담아 24시간 동안 물에 담근 후, 물 빼기를 하였다. 수분이 흡수된 옻나무 껍질을 $5 \mathrm{~L}$ 버섯재배 봉투에 옮겨 담고 필터를 달아 $121^{\circ} \mathrm{C}$ 에서 100 분 간 살균하였다. 전배양된 아까시재목버섯 균사체를 접종하 고 $21^{\circ} \mathrm{C}$ 에서 30 일간 배양한 후, $50^{\circ} \mathrm{C}$ 에서 열풍 건조시켜 무독화 발효 옻을 제조하였다. 믹서로 잘게 갈은 옻 1,000 $\mathrm{g}$ 에 10 배 $(\mathrm{w} / \mathrm{v})$ 의 증류수를 첨가한 후, 무게를 측정하고 고 압 살균기에 넣어 $110^{\circ} \mathrm{C}$ 에서 6 시간 동안 추출한 후, 증발된 수분량을 증류수로 보정하여 동일한 무게로 조정하였다. 발효 옻 조추출물은 광목천으로 여과하여 사용하였다.

\section{사용균주 및 배지조성}

본 연구에 사용된 균주는 국립농업과학원 농식품자원부 에서 보관중인 효모로 Table 1에 나타내었다. Saccharomyces cerevisiae Fermivin, Pichia kudriavzerii N77-4, Hanseniaspora opuntiae HP1-2, Candida tropicalis Y447, Wickerhamomyces anomalus N43-8, Pichia kluyveri Frootzen 6종을 YPD 고체 배지 (yeast extract $1 \%$, peptone $2 \%$, glucose $2 \%$, agar $2 \%$, $\mathrm{pH}$ 6.0)에서 $25^{\circ} \mathrm{C}, 48$ 시간 동안 배양하였다. 초산균은 Acetobacter pasteurianus KACC16934로 고체배지(glucose $3 \%$, yeast extract $0.5 \%, \mathrm{CaCO}_{3} 1 \%$, ethanol $3 \%$, agar $2 \%$, $\mathrm{pH}$ 7.0)에서 $30^{\circ} \mathrm{C}, 48$ 시간 동안 배양 한 후 $4^{\circ} \mathrm{C}$ 에 냉장보관하
면서 사용하였다.

Table 1. List of various yeast strains used in this study

\begin{tabular}{|c|c|c|c|}
\hline & Strain & Species & Source \\
\hline \multirow{2}{*}{$\begin{array}{c}\text { Commercial } \\
\text { yeast }\end{array}$} & Fermivin & $\begin{array}{l}\text { Saccharomyces } \\
\text { cerevisiae }\end{array}$ & $\begin{array}{l}\text { Strain } n^{\circ} 8906 \\
\text { Champagne, } \\
\text { France }\end{array}$ \\
\hline & Frootzen & Pichia kluyveri & $\begin{array}{l}\text { Wine, } \\
\text { New Zealand }\end{array}$ \\
\hline \multirow{4}{*}{$\begin{array}{l}\text { Selected } \\
\text { yeast }\end{array}$} & N77-4 & Pichia kudria vzevii & Nuruk, Seoul \\
\hline & HP1-2 & $\begin{array}{l}\text { Hanseniaspora } \\
\text { opuntiae }\end{array}$ & $\begin{array}{l}\text { Peach, suwon-si, } \\
\text { Gyeonggi-do }\end{array}$ \\
\hline & Y447 & Candida tropicalis & $\begin{array}{l}\text { Meju, } \\
\text { Gunsan-si, } \\
\text { Jeollabuk-do }\end{array}$ \\
\hline & N43-8 & $\begin{array}{l}\text { Wickerhamomyces } \\
\text { anomalus }\end{array}$ & $\begin{array}{l}\text { Nuruk, } \\
\text { Jeonju-si, } \\
\text { Jeollabuk-do }\end{array}$ \\
\hline
\end{tabular}

\section{알코올 발효 및 효모 접종}

6종의 효모를 첨가한 알코올 발효액 제조 방법은 Table 2 에 나타내었다. YPD 액체배지(yeast extract $1 \%$, peptone $2 \%$, glucose $2 \%, \mathrm{pH} 6.0)$ 에 각각의 효모를 $10 \%(\mathrm{v} / \mathrm{v})$ 접종하 여 $25^{\circ} \mathrm{C}, 48$ 시간 동안 배양하였다. 6 종의 효모 배양액을 1 단 담금 시 각각의 발효액에 $1.8 \mathrm{~mL}$ 씩 첨가하였으며, 이에 백국과 황국, 무독화 옻 추출물을 물과 잘 혼합하여 $25^{\circ} \mathrm{C}$, 24 시간 동안 발효하여 밑술을 만들었다. 1차 발효된 발효액 을 2 단 담금하여 $20^{\circ} \mathrm{C}, 8$ 일간 알코올 발효한 후 발효액을 광목천으로 여과하여 초산 발효에 사용하였다.

Table 2. Component of raw materials in detoxified Rhus verniciflua alcohol fermented liquor

\begin{tabular}{llcc}
\hline \multicolumn{1}{c}{ Ingredient } & Content (g) & Condition \\
\hline \multicolumn{2}{c}{ Rice nuruk (A oryzae, Chungmoo Fermentation) } & 200 & \\
1st & Rice nuruk (A luchuensis, Chungmoo Fermnetation) & 400 & $25^{\circ} \mathrm{C}$ \\
stage & Detoxified Rhus verniciflua extract & 800 & $24 \mathrm{hr}$ \\
mash & 100 & \\
Water & 1200 & \\
\hline \multicolumn{2}{c}{ Steamed rice (Glutinous rice) } & 1200 & \\
2nd Steamed rice (Non-glutinous rice) & 24 & $20^{\circ} \mathrm{C}$ \\
stage Commercial improved nuruk & 100 & \\
mash day & & & \\
Detoxified Rhus verniciflua extract & 3500 & \\
Water &
\end{tabular}

\section{종초 배양}

초산균인 $A$ pasteurianus KACC16934를 액체배지 (glucose $8.26 \mathrm{~g} / \mathrm{L}$, fructose $2.5 \mathrm{~g} / \mathrm{L}$, soy peptone $83.92 \mathrm{~g} / \mathrm{L}$, $\mathrm{MnSO}_{4} \cdot \mathrm{H}_{2} \mathrm{O} 0.088 \mathrm{~g} / \mathrm{L}$ )에 접종한 후 $30^{\circ} \mathrm{C}, 48$ 시간 동안 150 $\mathrm{rpm}$ 으로 진탕배양하여 원심분리 $\left(2,000 \mathrm{rpm}, 10 \mathrm{~min}, 4^{\circ} \mathrm{C}\right)$ 후 상등액을 제거하였다. 증류수로 3 회 세척 후, 효모를 달리 
한 무독화 옻으로 제조된 알코올 발효액에 초산균을 각각 $10 \%(\mathrm{v} / \mathrm{v})$ 로 접종하여 $30^{\circ} \mathrm{C}$ 에서 4 일간 정치배양하여 산도가 $3.5 \%$ 이상이 되었을 때 종초로 사용하였다.

\section{초산 발효}

$2 \mathrm{~L}$ 삼각플라스크에 무독화 옻 알코올 발효액 $800 \mathrm{~mL}$ 넣은 후 종초 $10 \%(\mathrm{v} / \mathrm{v})$ 를 접종하여 $30^{\circ} \mathrm{C}$ 의 항온 배양기에서 10 일간 정치 배양하였다.

\section{알코올 함량 분석}

알코올 함량은 시료 $100 \mathrm{~mL}$ 를 취하여 증류수 $100 \mathrm{~mL}$ 를 가한 후 가열 증류를 통하여 $80 \mathrm{~mL}$ 의 증류액을 얻었다. 이를 증류수로 이용하여 $100 \mathrm{~mL}$ 로 정용한 다음 비중계로 알코올 도수(\%)와 온도를 측정하고 국세청 보정표를 이용 하여 환산하였다(18).

\section{$\mathrm{pH}$ 및 적정산도}

$\mathrm{pH}$ 는 시료 $10 \mathrm{~mL}$ 를 취하여 $\mathrm{pH}$ meter(FE20, Mettler Toledo, Switzerland)로 측정하였으며, 적정산도는 시료 5 $\mathrm{mL}$ 에 $1 \%$ phenolphthalein 지시약을 2 3방울 떨어뜨린 후 $\mathrm{pH}$ 가 8.3이 될 때까지 $0.1 \mathrm{~N} \mathrm{NaOH}$ 용액으로 적정하여 acetic acid(\%)로 환산하였다. 적정 산도와 $\mathrm{pH}$ 모두 3회 반복 측정 후 평균값으로 나타내었다.

\section{유기산 분석}

옻식초의 유기산 분석을 위해 시료 $10 \mathrm{~mL}$ 를 원심분리 (3,500 rpm, $20 \mathrm{~min}, 4^{\circ} \mathrm{C}$ ) 후 상등액을 초순수(Fisher, HPLC water)를 이용해 산도 $0.2 \%$ 가 되도록 희석하였다. 희석한 시료를 Sep-pack C18 cartridge(Waters Oasis, Milfort, MA, USA)로 색소 및 단백질 성분을 제거하고 $0.45 \mu \mathrm{m}$ membrane filter(Millipore Co., Befford, MA, USA)로 여과하 였다. 시료는 HPLC(Chromaster 5000, Hitachi, Ltd, Tokyo, Japan)로 분석하였으며, ODS-100W(4.6 mm×250.0 mm) column을 사용하여 분석하였다. 이동상은 $3 \mathrm{mM}$ perchloric acid를 사용하였으며, flow rate는 $0.7 \mathrm{~mL} / \mathrm{min}$, column oven 의 온도는 $63^{\circ} \mathrm{C}$ 로 하였다. 분리물을 반응액 $(0.2 \mathrm{mM}$ bromothymol blue, $15 \mathrm{mM} \mathrm{Na}_{2} \mathrm{HPO}_{4}, 2 \mathrm{mM} \mathrm{NaOH}$ )과 혼합 시킨 후, UV $440 \mathrm{~nm}$ 에서 검출하였다. 이 때 반응액의 flow rate는 $0.9 \mathrm{~mL} / \mathrm{min}$ 으로 하였다.

\section{유리아미노산 분석}

옻식초의 유리아미노산 분석을 위해 시료를 $5 \%$ trichloroacetic acid(TCA)로 5 배 희석한 후 원심분리 $(10,000$ $\mathrm{rpm}, 15 \mathrm{~min}, 4^{\circ} \mathrm{C}$ )하여 상등액을 사용하였다. 상등액을 $\mathrm{n}$-Hexane으로 처리하여 비극성 물질을 제거한 후 하층액을 $0.2 \mu \mathrm{m}$ syringe filtering 후 아미노산 분석기(L-8900, Hitachi Co., Tokyo, Japan)로 분석하였으며 분석 조건은 Table 3과
같다.

Table 3. Operating condition of high performance liquid chromatography

\begin{tabular}{cl}
\hline Instrument & HITACHI L-8900 Amino acid analyzer \\
Main column & $\begin{array}{l}\text { HITACHI HPLC packed column \#2622PF column }(4.6 \times 60) \text { ion } \\
\text { exchange column }\end{array}$ \\
Solution & $\begin{array}{l}\text { Wako L-8500 Buffer solution PF-1, 2, 3, 4, RG Ninhydrin } \\
\text { coloring solution set }\end{array}$ \\
& VIS1 $: 570 \mathrm{~nm}$ \\
Detector & VIS2 : 440 nm \\
& UV detector \\
Injection & $20 \mu \mathrm{L}$ \\
\hline
\end{tabular}

\section{향기성분 패턴 분석}

옺식초의 향기 패턴 분석에 사용된 전자코는 metal oxide sensor(MOS)가 장착된 전자코 시스템(Fox 2000, Alpha MOS, Toluense, France)으로 시료 $1 \mathrm{~mL}$ 을 $10 \mathrm{~mL}$ 헤드 스페 이스 용기에 담아 밀봉 후 $4^{\circ} \mathrm{C}$ 에서 24 시간 방치하여 사용하 였다. Standard로는 신선한 공기(air)를 사용하였으며 시료 는 $80^{\circ} \mathrm{C}$ 에서 20 분간 $250 \mathrm{rpm}$ 으로 교반하였다. 주입구의 온도가 $130^{\circ} \mathrm{C}$ 인 상태에서 시료를 주입하였으며, 이 때 사용 된 가스는 공기로 분당 $150 \mathrm{~mL}$ 의 유속으로 분석하였다(19, 20).

\section{통계분석}

시료 분석은 3 회 반복하여 평균과 표준편차로 나타내었 다. 유기산 분석은 SPSS(12.0, SPSS Inc., Chicago, IL, USA) 통계 프로그램을 이용하여 일원배치분산분석(one-way ANOVA test)을 하고 $\mathrm{p}<0.05$ 수준에서 Duncan's multiple range test(DMRT)로 평균 간의 다중비교를 실시하였다.

\section{결과 및 고찰}

\section{효모 종류에 따른 무독화 옻 발효액의 알코올 함량}

본 실험에서는 효모 종류를 달리하여 알코올 발효액을 제조하였으며, 발효액의 알코올 함량은 Fig. 1과 같다. 발효 8 일 째 S. cerevisiae Fermivin의 알코올 함량이 $16.1 \%$ 로 가장 높게 나타났으며, H. pountiae HP1-2는 $15.1 \%, C$. tropicalis Y447은 13.7\%, P. kudriavzerii N77-4는 12.6\%, P. kluyveri Frootzen은 12.2\%, W. anomalus N43-8은 11.2\% 로 나타났다. 무독화 옻을 첨가한 알코올 발효액의 경우, 발효제의 사용량은 동일하지만 효모 종류에 따라 알코올 함량 차이가 있는 것으로 보여진다. 본 실험은 $\mathrm{Han}$ 등(21)이 보고한 누룩 종류를 달리한 탁주 술덧에서 발효 마지막 단계의 알코올 함량이 8.2 12.6\% 였다는 결과와 주모 제조 용 효모인 S. cerevisiae를 사용한 주모 첨가 탁주 술덧의 
알코올 함량이 7.2 8.5\%로 나타났다는 Baek 등(22)의 결과 보다 알코올 함량이 다소 높게 나타났다. 시험구별 알코올 함량은 Saccharomyces 속, Hanseniaspora 속, Candida속, Pichia 속, Wickerhamomyces 속 순으로 높은 경향을 보였다. 주모 제조 시 각 시험구에 첨가되는 효모의 양이 동일하다 는 판단 하에 발효 중에 생육하는 효모의 활성이 상이하여 알코올 함량에 차이를 보이는 것으로 생각된다.

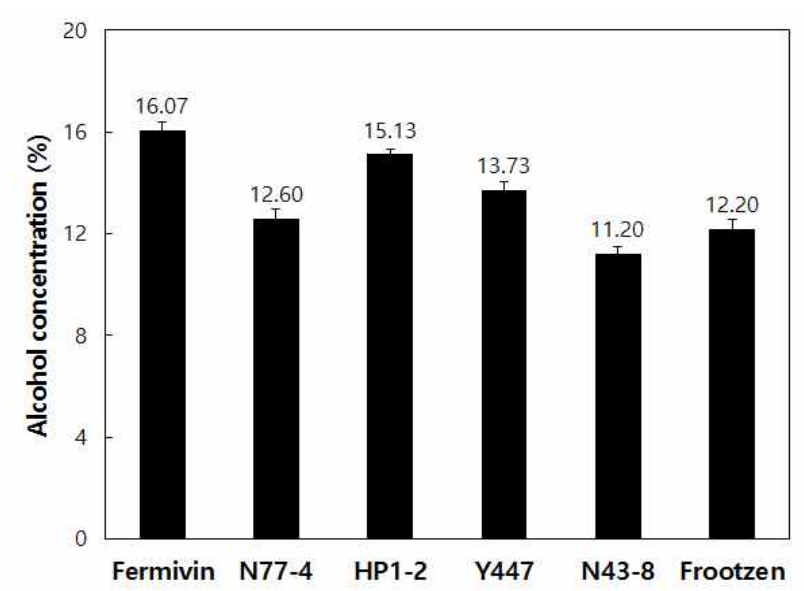

Fig. 1. Alcohol concentration of fermentation with various yeast strains.

Fermivin, Saccharomyces cerevisiae, N77-4, Pichia kudriavzerit, HP1-2, Hanseniaspora opuntiae, Y447, Candida tropicalis, N43-8, Wickerhamonyces anomalus, Frootzen, Pichia kluyveri.

\section{무독화 옻식초의 $\mathrm{pH}$ 및 적정산도}

효모 종류별 무독화 옻 발효액을 알코올 함량 $6 \%$ 로 조절 한 후, 종초 $10 \%(\mathrm{v} / \mathrm{v})$ 를 접종하여 초산 발효 특성을 조사하 였으며, 초산 발효에 따른 $\mathrm{pH}$ 변화를 Fig. 2에 나타내었다. 모든 시험구의 초기 $\mathrm{pH}$ 는 3.46 3.69이었으며 초산발효에 따라 $\mathrm{pH}$ 가 꾸준히 감소하는 경향을 보여 발효 10 일 째 2.87 3.06으로 나타났다. 특히 S. cerevisiae Fermivin은 발효 2 일에서 6 일까지 급격한 $\mathrm{pH}$ 의 감소와 발효 10 일 차 가장 낮은 결과를 보였다. 대부분의 식초는 초산발효 후, $\mathrm{pH}$ 2.87 2.91로 감소되었으나 $W$. anomalus N43-8은 초산발효 후 3.06으로 다른 시험구에 비해 비교적 높은 $\mathrm{pH}$ 를 유지하 였다. 효모 종류를 달리한 무독화 옻식초의 적정산도는 Fig. 3 에 나타내었으며, 모든 시험구에서 초산발효 10 일까지 산 도가 꾸준히 증가하여 5.17 6.66\%의 값을 보였다. 특히 $C$. tropicalis Y447의 경우, $6.66 \%$ 로 가장 높은 적정산도를 보 였으며, P. kluyveri Frootzen, P. kudiravzerii N77-4, S. cerevisiae Fermivin, $H$. pountiae HP1-2, $W$. anomalus N43-8 순으로 산도가 높게 나타났다.

\section{무독화 옻식초의 유기산 함량}

효모를 달리하여 제조한 무독화 옻식초의 유기산 함량을 Table 4에 나타내었다. 제조된 옻식초의 주요 유기산은

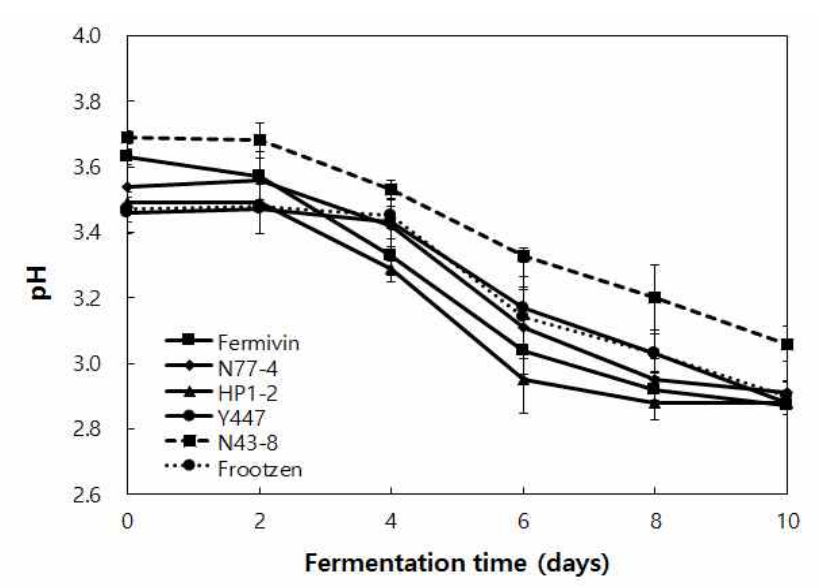

Fig. 2. Comparison of $\mathrm{pH}$ of vinegar produced by detoxified Rhus verniciflua of various yeast strains.

Fermivin, Saccharomyces cerevisiae, N77-4, Pichia kudriavzerï, HP1-2, Hanseniaspora opuntiae, Y447, Candida tropicalis, N43-8, Wickerhamomyces anomalus, Frootzen, Pichia kluyveri.

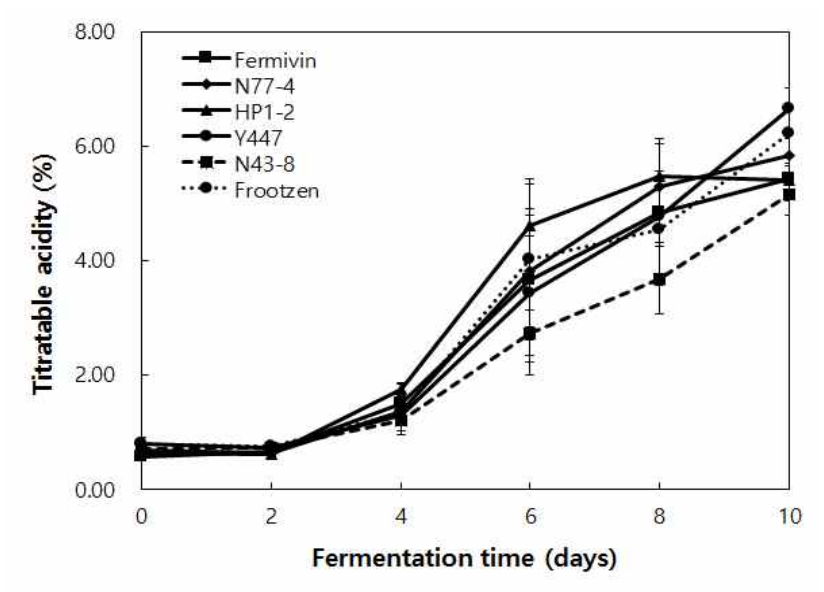

Fig. 3. Comparison of acidity of vinegar produced by detoxified Rhus verniciflua of various yeast strains.

Fermivin, Saccharomyces cerevisiae, N77-4, Pichia kudriaverii, HP1-2, Hanseniaspora opuntiae, Y447, Candida tropicalis, N43-8, Wickerhamomyces anomalus, Frootzen, Pichia kluyveri.

acetic acid로 나타났으며, 그 함량은 각각 $S$. cerevisiae Fermivin 48.7, P. kudiravzerii N77-4 50.7, H. pountiae HP1-2 44.3, C. tropicalis Y447 55.5, W. anomalus N43-8 35.9, $P$. kluyveri Frootzen $52.2 \mathrm{mg} / \mathrm{mL}$ 로 사용 효모 종류에 따라 약간 의 차이를 나타내었다. 가장 높은 함량을 보인 것은 $C$. tropicalis Y447이었으며, W. anomalus N43-8이 35.88 $\mathrm{mg} / \mathrm{mL}$ 로 유기산 함량이 가장 낮았다. 식초의 발효과정 중 초산균에 의해 생성되는 초산은 식초의 주성분으로 초산발 효의 관리 지침으로 알려져 있다(23). 곡물식초는 다른 식초 에 비해 젖산(lactic acid) 함량이 높으며(24), 젖산 함량이 높으면 군덕내의 원인으로 알려져 있다(25). 그러나 본 연구 에서는 acetic acid 외의 다른 유기산은 매우 미량으로 검출 되었으며, 이는 알코올 발효, 초산 발효 방식, 무독화 옻 
추출물 첨가 및 효모에 의한 것으로 보여진다. 식초에 따라 유기산 함량 차이는 원료와 원료 전처리법, 효모, 초산균, 알코올 및 초산발효 등에 따른 것으로 보고되어 있다(26).

Table 4. Acetic acid concentration of detoxified Rhus verniciflua vinegar by static fermentation with different yeast strain

(unit: $\mathrm{mg} / \mathrm{mL}$ )

\begin{tabular}{cc}
\hline Strains $^{1)}$ & Acetic acid \\
\hline Fermivin & $48.67 \pm 3.76^{\text {bc2 }}$ \\
N77-4 & $50.73 \pm 2.01^{\mathrm{c}}$ \\
HP1-2 & $44.28 \pm 1.47^{\mathrm{b}}$ \\
Y447 & $55.49 \pm 3.45^{\mathrm{d}}$ \\
N43-8 & $35.88 \pm 1.70^{\mathrm{a}}$ \\
Frootzen & $52.17 \pm 2.00^{\text {cd }}$ \\
\hline
\end{tabular}

${ }^{1}$ Fermivin, Saccharomyces cerevisiae, N77-4, Pichia kudriavzerii, HP1-2, Hanseniaspora opuntiae, Y447, Candida tropicalis, N43-8, Wickerhamomyces anomalus, Frootzen, Pichia kluyveri.

${ }^{2)}$ Data are means \pm SD of two independent experiments. Values displaying different superscript letter ${ }^{\text {add }}$ according to the Duncan test $(\mathrm{p}<0.05)$.

\section{무독화 옻식초의 유리아미노산 함량}

식초는 대체로 약 20 여 종의 유리아미노산이 검출되는 것으로 보고되고 있으며 그 종류에 따라 맛에 영향을 미치 는 것으로 알려져 있다(27). 효모 종류를 달리하여 제조된 무독화 옻식초의 유리아미노산 분석 결과는 Table 5에 나타 내었으며, 효모에 따라 유리아미노산 함량에 차이가 나타 났다. W. anomalus N43-8로 발효한 식초에서 2,411.7 $\mu \mathrm{g} / \mathrm{mL}$ 로 가장 높은 함량을 보였으며, S. cerevisiae Fermivin은 $1,314.9 \mu \mathrm{g} / \mathrm{mL}, P$. kudriavzerii N77-4은 1,753.9 $\mathrm{\mu g} / \mathrm{mL}, H$. opuntiae HP1-2은 $1,374.9 \mu \mathrm{g} / \mathrm{mL}, C$. tropicalis Y447은

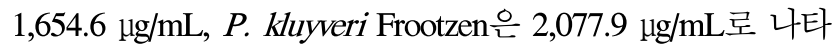
났다. 모든 시료에서 valine, leucine, isoleucine, lysine, threonine, phenylalanine 등 7종의 필수아미노산이 검출되 었으며 tryptophan은 검출되지 않았다. 식초의 산미를 부드 럽게 해주는 glutamic acid와 aspartic $\operatorname{acid}(25)$ 는 $W$. anomalus N43-8에서 $177.20 \mu \mathrm{g} / \mathrm{mL}, 133.24 \mu \mathrm{g} / \mathrm{mL}$ 로 다른 시험구에 비해 높은 결과를 나타내었다. 본 실험에서 제조 된 무독화 옻식초의 주요 아미노산은 glutamic acid와 alanine으로 나타났으며 S. cerevisiae Fermivin을 제외한 모 든 옻식초에서 phenylalanine과 생리활성 물질 $\mathrm{GABA}$ 의 전 구체인 arginine이 다량 검출되었다. Baek 등(28)에 따르면 무독화 옻식초는 valine, leucine, lysine, tyrosine 등의 함량 이 높다고 보고함에 따라 본 실험과 유사한 경향을 보였다. 일반적인 양조식초에 공통적으로 다량 함유된 아미노산은 aspartic acid, arginine, leucine, lysine, alanine 등으로 원료의 종류, 당화공정, 주정 발효의 조건이나 기타 각종 요인이 초산발효의 모든 단계에서 다르기 때문에 같은 식초라도
아미노산의 함량이 다르다고 보고된 바 있다(24). 무독화 옻식초의 유리아미노산의 함량은 각각의 식초마다 큰 차이 를 보였으며, 이는 효모의 종류에 기인하는 것으로 보여진 다.

\section{무독화 옻식초의 향기패턴 분석}

전자코(electronic nose)는 신속하고 편리하게 향기 패턴 을 분석할 수 있는 장점이 있어 본 연구에서는 식초의 복합 적인 향을 전자코 분석에 의해 시료 간 차이를 판별하고자 하였다. 식초의 향미(flavor)는 미생물 작용으로 다양한 휘 발성 성분이 생성된다. 식초는 초산 이외에 acid, aldehyde, alcohol, ketone, ester류 화합물의 상호작용에 의해 특유의 향미를 형성한다(29). 효모 종류를 달리하여 제조된 무독화 옻식초의 전자코를 이용한 향기 패턴을 비교하여 주성분 분석(PCA) 결과를 Fig. 4에 나타내었다. 그 중 가장 영향력 이 큰 함수 값인 $\mathrm{PC} 1$ 과 $\mathrm{PC} 2$ 를 중심으로 각 식초를 분석한 결과, 대조구로 사용된 공기는 $\mathrm{x}$ 축을 기준으로 가장 오른쪽 에 위치해 있었고 $\mathrm{y}$ 축을 기준으로 가장 위쪽에 위치하였다. 모든 무독화 옻식초는 standard인 신선한 공기를 기준으로 음의 방향에 위치하였으며 이 중 Fermivin, N77-4, Y447, $\mathrm{N} 43-8$ 의 $\mathrm{x}$ 축 값이 $-0.0133 \sim 0.127$ 로 나타났으며 $\mathrm{y}$ 축의 경우 -0.0181 -0.0262 값의 사이에 존재하여 Saccharomyces 속, Candida 속과 P. kudriavzevii는 비슷한 향기패턴을 갖는 것으로 나타났으며, Wickerhamomyces 속은 $\mathrm{x}$ 축, $\mathrm{y}$ 축으로 약간 양의 방향에 위치했다. Hanseniaspora 속과 P. kluyveri 는 다른 시험구에 비해 $\mathrm{x}$ 축은 음의 방향으로 위치했으며 $\mathrm{y}$ 축은 양의 값을 가졌다.

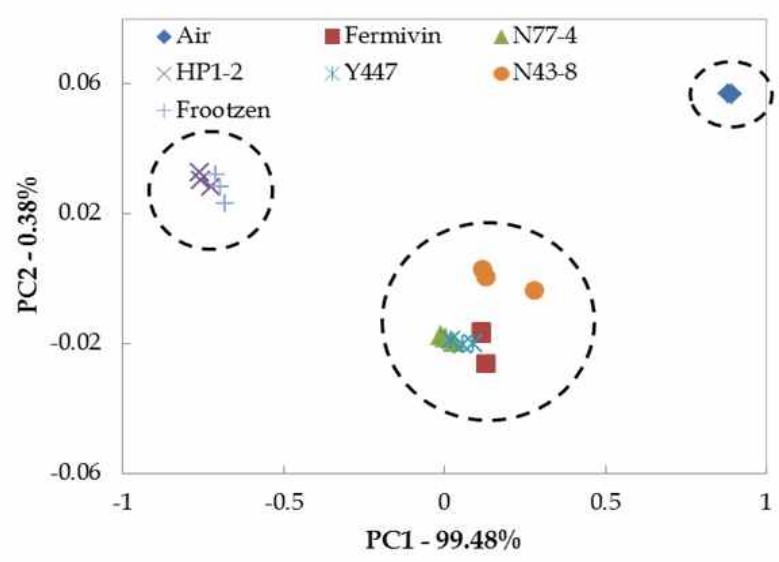

Fig. 4. PCA of the obtained data from electronic nose data for the flavor patterns of vinegar produced by detoxified Rhus verniciflua vinegar by fermentation with various yeast strains.

Fermivin, Saccharomyces cerevisiae, N77-4, Pichia kudriavzerii, HP1-2, Hanseniaspora opuntiae, Y447, Candida tropicalis, N43-8, Wickerhamomyces anomalus, Frootzen, Pichia kluyveri. 
Table 5. Free amino acid content in detoxified Rhus verniciflua vinegar by fermentation with various yeast strains

(unit: $\mu \mathrm{g} / \mathrm{mL}$ )

\begin{tabular}{|c|c|c|c|c|c|c|c|}
\hline & \multirow{2}{*}{ Free amino acid } & \multicolumn{6}{|c|}{ detoxified Rhus verniciflua vinegar by fermentation with different yeast strains } \\
\hline & & Fermivin $^{1)}$ & N77-4 & HP1-2 & Y447 & N43-8 & Frootzen \\
\hline \multirow{10}{*}{$\begin{array}{l}\text { Essential } \\
\text { amino acid }\end{array}$} & Valine & $75.93 \pm 14.49$ & $107.04 \pm 16.07$ & $93.94 \pm 0.49$ & $107.59 \pm 8.68$ & $141.30 \pm 15.63$ & $126.59 \pm 2.04$ \\
\hline & Leucine & $77.86 \pm 10.56$ & $113.45 \pm 15.11$ & $74.31 \pm 55.08$ & $132.26 \pm 11.65$ & $179.18 \pm 14.45$ & $149.66 \pm 2.58$ \\
\hline & Isoleucine & $40.04 \pm 4.49$ & $60.51 \pm 9.67$ & $53.48 \pm 0.75$ & $61.33 \pm 4.60$ & $83.33 \pm 7.58$ & $77.68 \pm 1.22$ \\
\hline & Lysine & $62.90 \pm 3.75$ & $79.19 \pm 4.46$ & $46.85 \pm 0.32$ & $60.85 \pm 28.64$ & $149.79 \pm 12.80$ & $70.74 \pm 1.24$ \\
\hline & Threonine & $39.45 \pm 1.41$ & $44.09 \pm 2.08$ & $27.90 \pm 0.33$ & $36.88 \pm 4.21$ & $57.65 \pm 2.44$ & $45.74 \pm 0.97$ \\
\hline & Methionine & $9.02 \pm 1.05$ & $17.79 \pm 6.90$ & $18.04 \pm 0.12$ & $20.73 \pm 3.08$ & $38.38 \pm 3.18$ & $30.77 \pm 0.85$ \\
\hline & Phenylalanine & $82.68 \pm 17.07$ & $117.25 \pm 27.25$ & $109.22 \pm 0.87$ & $126.68 \pm 9.50$ & $165.33 \pm 16.51$ & $150.60 \pm 1.95$ \\
\hline & Tryptophan & $\mathrm{nd}^{2)}$ & nd & nd & nd & nd & nd \\
\hline & Histidine & $37.44 \pm 0.41$ & $51.70 \pm 2.87$ & $32.74 \pm 0.18$ & $45.64 \pm 5.26$ & $63.38 \pm 3.45$ & $44.49 \pm 0.39$ \\
\hline & Total & 425.32 & 591.02 & 456.48 & 591.96 & 878.34 & 696.27 \\
\hline \multirow{11}{*}{$\begin{array}{l}\text { Non- } \\
\text { essential } \\
\text { amino acid }\end{array}$} & Aspartic acid & $45.54 \pm 9.28$ & $63.38 \pm 18.96$ & $45.43 \pm 0.03$ & $62.59 \pm 20.45$ & $133.24 \pm 14.06$ & $89.02 \pm 1.06$ \\
\hline & Serine & $57.91 \pm 3.90$ & $70.24 \pm 8.30$ & $42.28 \pm 0.36$ & $60.12 \pm 8.36$ & $95.38 \pm 3.59$ & $76.69 \pm 1.58$ \\
\hline & Glutamic acid & $110.62 \pm 18.79$ & $135.87 \pm 31.85$ & $118.72 \pm 4.83$ & $129.94 \pm 54.78$ & $177.20 \pm 22.29$ & $175.99 \pm 1.35$ \\
\hline & Glycine & $75.34 \pm 15.69$ & $90.06 \pm 14.60$ & $76.98 \pm 0.55$ & $108.75 \pm 32.27$ & $108.92 \pm 13.36$ & $114.32 \pm 1.80$ \\
\hline & Alanine & $150.22 \pm 40.95$ & $183.60 \pm 57.02$ & $120.94 \pm 6.09$ & $152.24 \pm 35.32$ & $188.57 \pm 36.23$ & $210.09 \pm 3.16$ \\
\hline & Cystine & $25.28 \pm 1.23$ & $30.74 \pm 2.68$ & $26.84 \pm 0.93$ & $32.76 \pm 3.83$ & $37.63 \pm 1.84$ & $32.97 \pm 0.60$ \\
\hline & Tyrosine & $107.36 \pm 28.79$ & $152.26 \pm 34.20$ & $121.02 \pm 0.84$ & $94.52 \pm 41.65$ & $198.11 \pm 23.89$ & $91.18 \pm 1.84$ \\
\hline & Arginine & $121.46 \pm 51.21$ & $137.44 \pm 51.27$ & $146.51 \pm 1.38$ & $137.65 \pm 63.11$ & $354.82 \pm 17.25$ & $114.23 \pm 2.15$ \\
\hline & Proline & $100.04 \pm 18.79$ & $70.55 \pm 8.12$ & $47.91 \pm 2.01$ & $49.64 \pm 10.78$ & $77.23 \pm 16.04$ & $59.96 \pm 1.62$ \\
\hline & Citrulline & nd & $6.36 \pm 5.55$ & nd & $4.68 \pm 4.12$ & nd & $10.25 \pm 0.07$ \\
\hline & Total & 793.77 & 940.50 & 746.63 & 832.89 & 1371.10 & 1069.80 \\
\hline \multirow{10}{*}{$\begin{array}{l}\text { Amino acid } \\
\text { derivative }\end{array}$} & a-amino adipic acid & $5.62 \pm 0.35$ & $10.10 \pm 3.19$ & $9.25 \pm 0.25$ & $7.73 \pm 1.85$ & $17.42 \pm 2.35$ & $12.77 \pm 0.10$ \\
\hline & Urea & $14.07 \pm 0.65$ & $11.21 \pm 9.94$ & $12.58 \pm 3.26$ & $8.13 \pm 7.07$ & nd & $16.11 \pm 1.80$ \\
\hline & Phosphoserine & $4.88 \pm 0.48$ & $5.07 \pm 0.48$ & $4.70 \pm 0.07$ & $5.88 \pm 1.12$ & $5.59 \pm 0.52$ & $5.77 \pm 0.10$ \\
\hline & Cystationine & $4.28 \pm 0.04$ & $4.84 \pm 0.29$ & $4.27 \pm 0.08$ & $3.85 \pm 1.52$ & $4.99 \pm 0.24$ & $4.76 \pm 0.12$ \\
\hline & 8-amino-n-butyric acid & $24.21 \pm 4.03$ & $32.36 \pm 5.85$ & $23.65 \pm 0.38$ & $29.05 \pm 4.53$ & $49.89 \pm 6.63$ & $37.82 \pm 0.65$ \\
\hline & Ethanol amine & $3.49 \pm 3.20$ & $9.87 \pm 8.54$ & nd & $6.66 \pm 3.55$ & $1.81 \pm 1.57$ & $9.83 \pm 0.24$ \\
\hline & Ammonia & $29.13 \pm 6.98$ & $27.10 \pm 11.78$ & $24.99 \pm 2.46$ & $20.52 \pm 5.93$ & $31.60 \pm 9.78$ & $18.24 \pm 1.14$ \\
\hline & Taurine & $0.97 \pm 0.12$ & $2.22 \pm 0.31$ & $0.89 \pm 0.08$ & $2.58 \pm 2.14$ & $2.50 \pm 1.08$ & $2.59 \pm 0.15$ \\
\hline & Total & 95.80 & 222.39 & 171.74 & 229.71 & 162.21 & 311.88 \\
\hline & Total & $1,314.89$ & $1,753.91$ & $1,374.85$ & $1,654.56$ & $2,411.65$ & $2,077.95$ \\
\hline
\end{tabular}

${ }^{1)}$ Fermivin, Saccharomyces cerevisiae, N77-4, Pichia kudriavzerii, HP1-2, Hanseniaspora opuntiae, Y447, Candida tropicalis, N43-8, Wickerhamomyces anomalus, Frootzen, Pichia kluyveri.

${ }^{2)}$ nd, Not detected.

\section{요 약}

본 연구는 무독화 옻 추출물을 첨가하여 효모 종류별로 제조한 옻식초의 품질 특성을 비교하였다. Saccharomyces cerevisiae Fermivin과 non-Saccharomyces 속인 Pichia, Hanseniaspora 속 등 6종의 효모를 이용하여 알코올 발효시
킨 결과, Fermivin이 알코올 함량이 가장 높았으며, Wickerhamomyces와 Pichia에서도 11.2, $12.2 \%$ 의 알코올 함 량을 나타내었다. 알코올 발효액에 초산균 A pasteurianus $\mathrm{KACC} 16934$ 를 접종하여 초산발효 시킨 결과 $\mathrm{pH}$ 와 적정 산도는 효모에 따른 차이가 있었다. W. anomalus N43-8을 제외한 모든 옻식초에서 발효 10 일 후 $\mathrm{pH} 3.0$ 이하로 나타났 
으며, 적정산도도 $W$. anomalus N43-8로 발효한 식초가 $5.17 \%$ 로 가장 낮게 나타났고 C. tropicalis Y447로 발효한 식초는 $6.66 \%$ 로 가장 높은 산도를 보였다. 옻식초의 주요 유기산으로 acetic acid가 검출되었으며 W. anomalus N43-8 식초의 유기산은 $35.88 \mathrm{mg} / \mathrm{mL}$ 로 가장 낮았고 C. tropicalis Y447 식초는 $55.49 \mathrm{mg} / \mathrm{mL}$ 로 높은 함량을 나타내었다. 유리 아미노산은 모든 시험구에서 valine, leucine 등의 필수아미 노산 7종이 검출되었으며 glutamic acid, alanine이 주요 아 미노산으로 확인되었다. 유리아미노산은 1,314.89 2,411.65 $\mathrm{\mu g} / \mathrm{mL}$ 로 효모의 종류에 따라 차이가 나타났다. 옻식초의 향기 패턴 분석 결과 $H$. opuntiae HP1-2와 P. kluyveri Frootzen이 비슷한 패턴을 보였으며, S. cerevisiae Fermivin 과 C. tropicalis Y447, P. kudria vzeri N77-4가 비슷한 패턴을 보였다. 두 그룹과 $W$. anomalus N43-8은 전자코 분석 결과 각각의 뚜렷한 향기 패턴을 보였다. 본 연구를 발효 특성이 다른 효모로 식초를 제조할 때, 각각의 효모에 따라 이화학 적 특성에 차이가 나는 것으로 보여진다.

\section{감사의 글}

This work was carried out with the support of "Cooperative Research Program for Agriculture Science and Technology Development (Project No. PJ01198402)" Rural Development Administration, Republic of Korea.

\section{References}

1. Casale M, Abajo MJS, Saiz JMG, Pizarro C, Forina M (2006) Study of the aging and oxidation processes of vinegar samples from different origins during storage by near-infrared spectroscopy. Analy Chim Acta 557, 360-366

2. Adams MR (1998) Vinegar. In: Microbiology of fermented food, Wood BJB (Editor), Blackie Academic and Professional, London, UK, p 1-44

3. Yim EJ, Jo SW, Lee ES, Park HS, Ryu MS, Uhm TB, Kim HY, Cho SH (2015) Fermentation characteristics of mulberry (Cudrania tricuspidata) fruit vinegar produced by acetic acid bacteria isolated from traditional fermented foods. Korean J Food Preserv, 22, 108-118

4. Ann YG, Kim SK, Shin CS (2001) Studies on wax gourd-ginseng vinegar. Korean J Food Nutr, 14, 52-58

5. Seo HB, Song YJ, Kang JY, Kwon DK, Kim PG, Ryu SP (2011) The study of persimmon vinegar as a functional drink on reduce blood lipids and enhance exercise performance. Jour Korean For Soc, 100, 232-239

6. Kim MJ, Choi JH, Kwon SH, Kim HD, Bang MH, Yang SA (2013) Characteristics of fermented dropwort extract and vinegar using fermented dropwort extract and its protective effects on oxidative damage in rat glioma C6 cells. Korean J Food Sci Technol, 45, 350-355

7. Na HS, Choi GC, Yang SI, Lee JH, Cho JY, Ma SJ, Kim JY (2013) Comparison of characteristics in commercial fermented vinegars made with different ingredients. Korean J Food Preserv, 20, 482-487

8. Hong SM, Moon HS, Lee JH, Lee HI, Jeong JH, Lee MK, Seo KI (2012) Development of functional vinegar by using cucumbers. Korean J Soc Food Sci Nutr, 41, 927-935

9. Jung NC (1998) Biological activity of urushiol and flavonoids from Lac tree (Rhus verniciflua Stokes). $\mathrm{Ph}$ D Thesis, Chonnam National University, Gwangju, Korea, p 9-21

10. Kim JB (2003) Identification of antioxidative component from stem bark of Rhus verniciflua. Korean J Food Nutr, $16,60-65$

11. Son YO, Lee KY, Lee JC, Jang HS, Kim JG, Jeon YM, Jang YS (2005) Selective antiproliferative and apoptotic effects of flavonoids purified from Rhus verniciflua Stokes on normal versus transformed hepatic cell lines. Toxicol Lett, 155, 115-125

12. Kim JS, Kwon YS, Chun WJ, Kim TY, Sun JH, Yu CY, Kim MJ (2010) Rhus verniciflua Stokes flavonoid extracts have anti-oxidant, anti-microbial and a -glucosidase inhibitory effect. Food Chem, 120, 539-543

13. Ha YD, Kim KS (2000) Civilization history of vinegar. Food Industry and Nutrition, 5, 1-6

14. Jang SY, Jeong YJ (2005) Effect of lactate and corn steep liquor on the production of bacterial cellulose by Gluconobacter perimmonis KJ145T. Food Sci Biotechnol, 5, 561-565

15. Jones DD, Greenshields RN (1970) Volatile constituents of vinegar. П. Fermation of volatiles in a commercial malt vinegar process. J Inst Brew, 76, 55-60

16. Kim AR, Lee SY, Kim KBWR, Song EJ, Kim JH, Kim MJ, Ji KW, Ahn IS, Ahn DH (2008) Effects of Glycyrrhiza uralensis on shelf-life and quality of Takju. Korean J Food Sci Technol, 40, 194-200

17. Choi HS, Yeo SH, Jeong ST, Choi JH, Park HS, Kim MK (2012) Preparation and characterization of urushiol free fermented Rhus verniciflua stem bark (FRVSB) extracts. Korean J Food Sci Technol, 44, 173-178 
18. Kim JY, Yi YH (2010) pH, acidity, color, amino acids, reducing sugars, total sugars and alcohol in puffed millet powder containing millet Takju during fermentation. Korean J Food Sci Technol, 42, 727-732

19. Shin JA, Choi SW, Lee KT (2005) Prediction of kimchi aging using electronic nose system. Korean J Food Preserv, 12, 613-616

20. Jo IH, Kim HS, Kim GM, Kim JS, Kim GC (2012) Effects of packaging method on the quality of blanched Namul during storage. Korean J Food Preserv, 19, 328-336

21. Han EH, Lee TS, Noh BS, Lee DS (1997) Volatile flavor components in mash of Takju prepared by using different Nuruks. Korean J Food Sci Technol, 29, 563-570

22. Baek SY, Lee YJ, Kim MD, Yi JH, Mun JY, Yeo SH (2015) Characterization of ethanol fermentation with wild type yeast strains. Microbial Biotechnol Lett, 43, 227-235

23. Moon SY, Chung HC, Yoon HN (1997) Comparative analysis of commercial vinegars in physicochemical properties, minor components and organoleptic tastes. Korean J Food Sci Technol, 29, 663-670
24. Furukawa S, Takenaka N, Ueda R (1973) Conversion of non-vilatile organic acids to acetic acid in acetic acid fermentation. J Ferment Technol, 51, 327-334

25. Lee YC, Jang OY, Kim HW, Choi CU, Yoon SK (1999) Physicochemical characteristics of traditional vinegars in Andong province. J Korean Soc Food Cult, 14, 17-20

26. Shin JS, Jeong YJ (2003) Changes in the components of acetic acid fermentation of brown rice using raw starch digesting enzyme. J Korean Soc Food Sci Nutr, 32, 381-387

27. Jeong YJ, Lee MH (2000) A view and prospect of vinegar industry. Food Industry and Nutrition, 5, 7-12

28. Baek SY, Kim JS, Mun JY, Lee CH, Park YK, Yeo SH (2016) Quality characteristics of detoxified Rhus verniciflua vinegar fermented using different acetic acid bacteria. Korean J Food Preserv, 23, 347-354

29. Seo JH, Park NY, Jeong YJ (2001) Volatile components in persimmon vinegars by solid phase microextraction. Korean J Food Sci Technol, 33, 153-156 